\title{
ANTIMICROBIALACTIVITY OF SODIUM HYPOCHLORITE ASSOCIATED WITH INTRACANAL MEDICATION FOR Candida albicans AND Enterococcus faecalis INOCULATED IN ROOT CANALS
}

\author{
Marcia Carneiro VALERA ${ }^{1}$, Katy Costa Godinho da SILVA ${ }^{2}$, Lilian Eiko MAEKAWA ${ }^{3}$, Cláudio Antonio Talge CARVALHO ${ }^{4}$, \\ Cristiane Yumi KOGA-ITO ${ }^{5}$, Carlos Henrique Ribeiro CAMARGO ${ }^{4}$, Raphael Silva e LIMA ${ }^{2}$
}

\author{
1- DDS, MSc, PhD, Adjunct Professor, Department of Restorative Dentistry, São José dos Campos Dental School, São Paulo State University, São José \\ dos Campos, SP, Brazil. \\ 2- DDS, Undergraduate student, Department of Restorative Dentistry, São José dos Campos Dental School, São Paulo State University, São José dos \\ Campos, SP, Brazil. \\ 3- DDS, MSc Graduate student, Department of Restorative Dentistry, São José dos Campos Dental School, São Paulo State University, São José dos \\ Campos, SP, Brazil. \\ 4- DDS, MSc, PhD, Assistant Professor, Department of Restorative Dentistry, São José dos Campos Dental School, São Paulo State University, São \\ José dos Campos, SP, Brazil. \\ 5- DDS, MSc, PhD, Adjunct Professor, Department of Oral Diagnosis and Biosciences, Department of Restorative Dentistry, São José dos Campos \\ Dental School, São Paulo State University, São José dos Campos, SP, Brazil.
}

Corresponding address: Dra. Marcia Carneiro - Av. Engenheiro Francisco José Longo, 777 - Jd. São Dimas - 12245-000 - São José dos Campos, SP Brasil.- Phone: +55-12-3947-9048 - e-mail: marcia@fosjc.unesp.br

Received: August 27, 2008 - Modification: January 19, 2009 - Accepted: May 18, 2009

\begin{abstract}
bjective: The purpose of this study was to evaluate the action of sodium hypochlorite $(\mathrm{NaOCl})$ associated with an intracanal medication against Candida albicans and Enterococcus faecalis inoculated in root canals. Material and Methods: Thirty-six human single-rooted teeth with single root canals were used. The canals were contaminated with C. albicans and E. faecalis for 21 days and were then instrumented with $1 \% \mathrm{NaOCl}$. The roots were divided into 3 groups $(n=12)$ according to the intracanal medication applied: calcium hydroxide paste, $2 \%$ chlorhexidine (CHX) gel, and 2\% $\mathrm{CHX}$ gel associated with calcium hydroxide. The following collections were made from the root canals: a) initial sample (IS): 21 days after contamination (control), b) S1: after instrumentation, c) S2: 14 days after intracanal medication placement; S3: 7 days after intracanal medication removal. The results were analyzed statistically by the Kruskal-Wallis test at 5\% significance level. Results and Conclusions: Both $1 \% \mathrm{NaOCl}$ irrigation and the intracanal medications were effective in eliminating E. faecalis and C. albicans inoculated in root canals.
\end{abstract}

Key words: Sodium hypochlorite. Chlorhexidine. Calcium hydroxide. Candida albicans. Enterococcus faecalis.

\section{INTRODUCTION}

The microorganisms and their products are closely related to the etiology of pulpal and periapical lesions. They can cause pulp necrosis due to their persistence in the root canal system after endodontic treatment and can induce a periapical inflammatory reaction ${ }^{13}$.

The polymicrobial nature of endodontic infections has been demonstrated. The root canal flora is formed by more than 700 different species and some of them have not yet

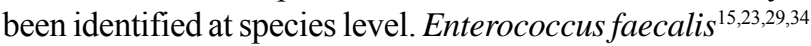
has been frequently isolated in root canals with pulpal infection and also in secondary/persistent endodontic infections. In addition to bacteria, other microorganisms like yeasts can be found in root canals with pulp necrosis ${ }^{18}$. Yeasts are particularly associated with persistent root canal infections that do not respond favorably to conservative root canal therapy ${ }^{31}$. Najzar-Fleger, et al. ${ }^{19}$ observed that $55 \%$ of root canals had yeasts of this type and Waltimo, et al. ${ }^{30}$ verified for the polymerase chain reaction (PCR) analysis the presence of Candida spp. in root canals.

During biomechanical preparation, several chemical substances are used as irrigants. Due to a series of properties such as the capacity to dissolve the organic matter, lubrication and toxic content neutralization, sodium hypochlorite $(\mathrm{NaOCl})$ is currently the most commonly used substance $e^{3,24,33}$. However, even after biomechanical preparation with antimicrobial substances, some microorganisms may survive in the root canal system, requiring disinfection by the use of an intracanal medication, 
which will act beyond the root canal lumen, inside of dentinal tubules and apical resorptions ${ }^{1,6,9,11}$.

Calcium hydroxide has been widely used as an intracanal medication due to its antimicrobial properties ${ }^{1,17,25}$, especially due to its action over Gram-negative bacteria. However, it has a limited action against some microorganisms, particularly E. faecalis $^{9}$ and Candida albicans ${ }^{2}$. Estrela, et al. ${ }^{8}$ verified that calcium hydroxide $(\mathrm{CH})$ requires 60 days to have an antimicrobial effect on C. albicans and E. faecalis cultures. In failed root canal treatments, $2 \%$ chlorhexidine (CHX) gel may be a more effective intracanal medication than $\mathrm{CH}$ paste or their combination against $C$. albicans and E. faecalis ${ }^{2}$. In vitro studies have shown that when in direct contact, $\mathrm{CH}$ eliminated microorganisms present in the root canals ${ }^{28}$. However, in vivo studies have not reported similar performance in the root canal system ${ }^{26,27}$.

The association of $\mathrm{CH}$ and $2 \% \mathrm{CHX}$ has been used as intracanal dressing with encouraging results since it enhances the antimicrobial action of the paste against endodontic pathogens ${ }^{6,10}$. The purpose of this study was to evaluate the effect of biomechanical preparation with $1 \% \mathrm{NaOCl}$ irrigation followed by intracanal medication with $\mathrm{CH}$ paste, $2 \% \mathrm{CHX}$ gel and the association of these substances against E. faecalis and C. albicans inoculated in root canals.

\section{MATERIAL AND METHODS}

The present study was approved by the Research Ethics Committee of São José dos Campos Dental School, São Paulo State University, Brazil (Protocol \#093/2005). Thirtysix freshly extracted human single-rooted teeth maintained in saline storage were used. The crowns were removed to provide a standardized root length of $16 \pm 0.5 \mathrm{~mm}$. The root canals were overinstrumented at $0.5 \mathrm{~mm}$ up to a size 25 K-file (Dentsply Ind. Com. Ltda, Petrópolis, RJ, Brazil), followed by instrumentation at $1 \mathrm{~mm}$ short of the apical foramen up to a size $30 \mathrm{~K}$-file.

The external root surfaces were coated with epoxy resin (Araldite, Brascola, São Paulo, SP, Brazil), except for the coronal opening and apical foramen. The root canals were filled with 17\% EDTA for $3 \mathrm{~min}$ and rinsed with $5 \mathrm{~mL}$ of saline. The apical foramen was then sealed with light-cured composite resin (Z-100; 3M ESPE, St. Paul, MN, USA) and the roots were autoclaved at $121{ }^{\circ} \mathrm{C}$ for $15 \mathrm{~min}$. Thereafter, the roots were joined to clear light-cured acrylic resin (Dencor; Artigos Odontológicos Clássico, São Paulo, SP, Brazil) in 24-well plates (Costar, Corning, NY, USA), which were sterilized by cobalt 60 gamma radiation $(20 \mathrm{KGy}$ for $6 \mathrm{~h})$.

The microorganisms used were C. albicans (ATCC 18804) and E. faecalis (ATCC 29212). C. albicans was plated on Petri plates containing Sabouraud Dextrose agar (Himedia Laboratories, Mumbai, India) and incubated in a microbiological oven at $37 \pm 1^{\circ} \mathrm{C}$ for $24 \mathrm{~h}$. E. faecalis had been previously grown in Brain Heart Infusion (BHI) broth (Himedia Laboratories, Mumbai, India) for $48 \mathrm{~h}$, and was then seeded on plates containing BHI agar BHI and incubated in a humidified incubator with $5 \% \mathrm{CO}_{2}$ at $37 \pm$ $1^{\circ} \mathrm{C}$ for $48 \mathrm{~h}$.

C. albicans and E. faecalis saline suspensions containing $10^{8}$ cells $/ \mathrm{mL}$ were prepared, corresponding to 1,258 optical density in the spectrometer at $530 \mathrm{~nm}$ wavelength $(C$. albicans) and 1,258 optical density in the spectrometer at $760 \mathrm{~nm}$ wavelength (E. faecalis). The root canals were contaminated with $5 \mathrm{~mL}$ of each microbial suspension plus $10 \mathrm{~mL}$ BHI and $10 \mathrm{~mL}$ Sabouraud broth, totalizing $30 \mathrm{~mL}$ inoculated in the root canal ${ }^{17}$. A sterile cotton ball was placed in the root canal opening and the coronal opening was sealed with a noneugenol, self-setting, single-component temporary coronal filling material (Coltosol; Coltene-Whaledent, Cuyahoga Falls, OH, USA). The plates were incubated in a microbiological oven at $37^{\circ} \mathrm{C} \pm 1^{\circ} \mathrm{C}$ for 21 days and the culture medium (BHI broth) was added every 3 days to the root canals ${ }^{17}$

At the end of the contamination period, microbiological samples were collected to confirm contamination of root canals by the test microorganisms (control for each group). After control collection, the root canals were instrumented up to a size $50 \mathrm{~K}$-file with $5 \mathrm{~mL}$ of $1 \% \mathrm{NaOCl}$ at each change of instrument and 3 groups were formed $(n=12)$ according to the intracanal medication: $\mathrm{CH}$ paste $\left(\mathrm{Calen}^{\circledR}\right.$ paste; $\mathrm{SS}$ White, Rio de Janeiro, RJ, Brazil; composition: $2.5 \mathrm{~g} \mathrm{CH}$, $0.5 \mathrm{~g}$ zinc oxide, $0.05 \mathrm{~g}$ colophony and $1.75 \mathrm{~mL}$ polyethylene glycol 400 (vehicle)); 2\% CHX gel (Byoformula Drugstore, São José dos Campos, SP, Brazil); 2\% CHX gel associated with $\mathrm{CH}$ powder (Inodon; Porto Alegre, RS, Brazil), at 1:1 mixing ratio ${ }^{11}$.

The following collections were made from the root canal: a) initial sample (IS): 21 days after contamination (control), b) S1: after instrumentation with $1 \% \mathrm{NaOCl}$ irrigation, c) S2: 14 days after placement of the intracanal medication; S3: 7 days after removal of the medication. Between S2 and $\mathrm{S} 3$, the canals were filled with sterile saline.

Before the first collection of microbiological samples (IS), the roots were irrigated with $0.06 \%$ sodium thiosulfate for $\mathrm{NaOCl}$ neutralization. All collections from root canals, namely immediately after instrumentation (S1), 14 days after intracanal medication (S2), and after 7 days after removal of the medication and filling with saline (S3), were made in the same way. A sterile size 50 paper point was left in the root canal for $1 \mathrm{~min}$. After this time, each paper point was placed in an Eppendorf test tube containing $0.5 \mathrm{~mL}$ of sterile saline, shaken for $30 \mathrm{~s}$, and $0.1 \mathrm{~mL}$ of the microbial suspension were double seeded on plates containing culture medium for C. albicans and E. faecalis. After growth check, the formation of E. faecalis and C. albicans colonies was confirmed by Gram staining under light microscopy. Data were analyzed statistically by the Kruskal-Wallis test at a significance level of $5 \%$.

\section{RESULTS}

The mean values of colony forming units (cfu) $/ \mathrm{mL}$ obtained in the groups after confirmation collection (SI - 
TABLE 1- Mean values of cfu/mL obtained in the groups after confirmation collection (SI - control), 1st collection (biomechanical preparation - S1), 2nd collection (14 days after placement of the intracanal medication - S2) and 3rd collection (7 days after removal of the of intracanal medication)

\begin{tabular}{|c|c|c|c|c|c|c|c|c|}
\hline \multirow[t]{2}{*}{ Group } & \multicolumn{2}{|c|}{$\begin{array}{c}\text { Confirmation } \\
\text { collection (IS-control) }\end{array}$} & \multicolumn{2}{|c|}{ 1st collection (S1) } & \multicolumn{2}{|c|}{ 2nd collection (S2) } & \multicolumn{2}{|c|}{ 3rd collection (S3) } \\
\hline & $\begin{array}{c}\text { C. } \\
\text { albicans }\end{array}$ & $\begin{array}{c}E . \\
\text { faecalis }\end{array}$ & $\begin{array}{c}\text { C. } \\
\text { albicans }\end{array}$ & $\begin{array}{c}E . \\
\text { faecalis }\end{array}$ & $\begin{array}{c}\text { C. } \\
\text { albicans }\end{array}$ & $\begin{array}{c}\text { E. } \\
\text { faecalis }\end{array}$ & $\begin{array}{c}\text { C. } \\
\text { albicans }\end{array}$ & $\begin{array}{c}E . \\
\text { faecalis }\end{array}$ \\
\hline $\mathrm{CH}$ paste & 1414.22 & 272.08 & 0.208 & 1.708 & 0 & 0 & 2.66 & 0 \\
\hline $2 \% \mathrm{CHX}$ gel & 2441.25 & 342 & 0.166 & 0.25 & 0.083 & 17.50 & 0.166 & 0.125 \\
\hline $\mathrm{CH}+2 \% \mathrm{CHX}$ gel & 1455.16 & 377.66 & 0 & 0 & 0 & 0 & 0 & 0 \\
\hline
\end{tabular}

IS = initial sample; $\mathrm{CH}=$ calcium hydroxide; $\mathrm{CHX}=$ chlorhexidine; cfu= colony forming units

control), 1st collection (biomechanical preparation - S1), 2nd collection (14 days after placement of the intracanal medication - S2) and 3rd collection (7 days after removal of the of intracanal medication). are presented in Table 1.

Statistically significant difference $(p<0.05)$ was found between the IS and S1. Considering that after placement of the intracanal medication the mean $\mathrm{cfu} / \mathrm{mL}$ values of both C. albicans and $E$. faecalis were the same or close to zero, there was no need to apply the statistical test to the results.

No statistically significant differences $(p>0.05)$ were found between the intracanal medications against $C$. albicans and E. faecalis.

\section{DISCUSSION}

Biomechanical preparation with $\mathrm{NaOCl}$ has been proven effective in eliminating microorganisms present in the root canal system. Even though the antimicrobial action of $\mathrm{NaOCI}$ has not yet been fully understood, hypochlorite acid is formed in the presence of water containing active chlorine, a powerful oxidizing agent that produces an antimicrobial effect by irreversible oxidation of hydrosulphuric groups of essential enzymes, disturbing the metabolic functions of the bacterial cell. Chlorine can also adhere to bacterial cytoplasm components forming highly toxic $\mathrm{N}$-chloro composites that destroy the microorganisms ${ }^{24}$.

Byström and Sundqvist ${ }^{4}$ reported that $0.5 \% \mathrm{NaOCI}$ was more effective than saline as an irrigant, confirming the antimicrobial properties of that substance. Although less concentrated solutions have shown antimicrobial effectiveness $^{24}$, higher concentrations of $\mathrm{NaOCI}$ present faster and greater bactericidal effect ${ }^{10,22}$. However, the higher the concentration of this substance, the greater its cytotoxic effect $^{10,22}$. In the present study, $1 \% \mathrm{NaOCl}$ was effective to considerably reduce $C$. albicans and E. faecalis counts immediately after root canal preparation.

Nevertheless, $\mathrm{NaOCl}$ has limited capacity to penetrate into the dentinal tubules. Vahdaty, et al. ${ }^{32}$ observed the antimicrobial action of $\mathrm{NaOCI}$ against $\mathrm{E}$. faecalis up to 500$\mu \mathrm{m}$ deep, while Sen, et al. ${ }^{21}$ reported that, even when 5.25\% $\mathrm{NaOCI}$ was used, it was impossible to eliminate C. albicans from human dentin sections after 1-h exposure. Berutti, et $\mathrm{al}^{3}{ }^{3}$ observed an increase in the antibacterial effect of 5.0\% $\mathrm{NaOCI}$ when used alternately with $10 \%$ EDTA solution. This is related to the demineralizing action of EDTA, which prevents smear layer formation during instrumentation, resulting in an increased $\mathrm{NaOCI}$ penetration into the dentinal tubules.

In the present study, the groups dressed with calcium hydroxide paste and 2\% CHX gel exhibited a considerable decrease in the number of $\mathrm{cfu} / \mathrm{mL}$ after biomechanical preparation with $\mathrm{NaOCI}$ irrigation (S1), while the group dressed with $2 \%$ CHX gel plus calcium hydroxide presented total elimination of microorganisms at $\mathrm{S} 1$. It must be considered that no microorganisms were expected to be found after that collection. It is likely that if the same canals had been filled with saline and sealed for 7 days they would have shown contamination due to migration of microorganisms that had remained in the dental tubules and branches of the root canal system, as reported elsewhere ${ }^{17}$. However, the purpose of this study was to evaluate the biomechanical preparation using an irrigant with antimicrobial activity followed by placement of intracanal medication simulating the clinical conditions. The use of an intracanal medication could reduce or even eliminate the microorganisms inoculated in the root canal, as demonstrated by the empty canals at 7 days after removal of medication.

Sodium thiosulfate $0.06 \%$ and tween $80 \%+$ lecithin $0.07 \%$ are well known substances in neutralizing the residual activity of $\mathrm{NaOCl}$ and $\mathrm{CHX}$. However, an adequate $\mathrm{CH}$ neutralizer solution has not been found. Therefore, in order to standardize the experimental conditions of the present study, no neutralizer was used after 14 days of intracanal medication.

The 2\% CHX gel showed optimal antimicrobial action against E. faecalis and C. albicans, resulting in microbiological collections close to zero or minimum growth (S2). Then, it was noted that after removal of the intracanal medication, the number of $\mathrm{cfu} / \mathrm{mL}$ of $E$. faecalis was higher than after S3. It is likely that the action of the intracanal medication during 14 days was not sufficient to eliminate E. faecalis. However, the residual effect of $2 \% \mathrm{CHX}$ gel completed the action initiated when the medication was in 
the root canal. Even so, complete elimination of microorganisms was not observed. Previous studies using $2 \%$ CHX gel as a chemical auxiliary substance to biomechanical preparation showed its effectiveness against microorganisms present in the root canal ${ }^{5,12,14}$. The CHX acts by electrostatic interaction, that is, it is positively charged and the bacterial wall is negatively charged. This interaction increases the cell wall coating, allowing bacterial cytoplasm coagulation, resulting in cell death ${ }^{7}$.

In this study, it was noted that the association of $\mathrm{CH}$ and $\mathrm{CHX}$ as intracanal medication was able to keep the root canal free from microorganisms that could possibly remain inside the dentinal tubules after biomechanical preparation. The mechanism of action of this association is the same as the $\mathrm{CH}$ and $\mathrm{CHX}$. The $\mathrm{CH}$, associated or not with other substances, is the most used medication as root canal dressing in Endodontics ${ }^{24,33}$. Its antimicrobial activity is primarily related to the release of hydroxyl ions with consequent $\mathrm{pH}$ increase, as well as the action of hydroxyl ions on the inactivation of enzymes of the cytoplasmic membrane of bacteria, which influences the chemical transportation and alteration in the availability of nutrients, causing toxic effects to the bacterial cells ${ }^{25}$. McHugh, et al. ${ }^{16}$ reported that the $\mathrm{pH}$ between 10.5 and 11 delays the growth of $E$. faecalis and that only a $\mathrm{pH}$ higher than 11 can eliminate this microorganism. In the present study, the $\mathrm{CH}$ paste completely eliminated the microorganisms at the $2 \mathrm{nd}$ collection (S2) and permitted only minimum growth of $C$. albicans at the 3 rd collection (S3). These results show the effectiveness of this medication against $E$. faecalis and $C$. albicans. The association of $\mathrm{CH}$ and $\mathrm{CHX}$ combines the antimicrobial properties of $\mathrm{CHX}$ against other microorganisms not tested in the present study $^{7,11}$ with the mineralization potential and neutralization properties against endotoxins of $\mathrm{CH}^{20}$.

\section{CONCLUSION}

Biomechanical preparation with $1 \% \mathrm{NaOCl}$ irrigation considerably reduced $C$. albicans and $E$. faecalis counts in contaminated root canals. The tested intracanal medications were also able to produce a significant decrease in the number of microorganisms, so that the association of $\mathrm{CH}$ and $\mathrm{CHX}$ maintained the root canals completely free from microorganisms.

\section{REFERENCES}

1- Athanassiadis B, Abbott PV, Walsh LJ. The use of calcium hydroxide, antibiotics and biocides as antimicrobial medicaments in endodontics. Aust Dent J. 2007;52(1 suppl):64-82.

2- Ballal V, Kundabala M, Acharya S, Ballal M. Antimicrobial action of calcium hydroxide, chlorhexdine and their combination on endodontic pathogens. Aust Dent J. 2007;52(3):257.

3- Berutti E, Marini R, Angeretti A. Penetration ability of different irrigants into dentinal tubules. J Endod. 1997;23(12):725-7.
4- Byström A, Sundqvist G. Bacteriologic evaluation of the effect of 0,5 percent sodium hypochlorite in endodontic therapy. Oral Surg Oral Med Oral Pathol. 1983;55(3):307-12.

5- Dametto FR, Ferraz CCR, Gomes BPFA, Zaia AA, Teixeira FB, Souza FJ Filho. In vitro assessment of the immediate and prolonged antimicrobial action of chlorhexidine gel as an endodontic irrigant against Enterococcus faecalis. Oral Surg Oral Med Oral Pathol Oral Radiol Endod. 2005;99(6):768-72.

6- Ercan E, Dalli M, Dulgergil T. In vitro assessment of the effectiveness of chlorhexidine gel and calcium hydroxide paste with chlorhexidine against Enterococcus faecalis and Candida albicans. Oral Surg Oral Med Oral Pathol Oral Radiol Endod. 2006;102(2):27-31.

7- Ercan E, Ozekinci T, Atakul F, Gul K. Antibacterial activity of 2\% chlorhexidine gluconate and $5.25 \%$ sodium hypochlorite in infected root canal: in vivo study. J Endod. 2004;30(2):84-7.

8- Estrela C, Cynthia RA, Pécora JD. A study of the time necessary for calcium hydroxide to eliminate microorganisms in infected canals. J Appl Oral Sci. 2003;11(2):133-7.

9- Estrela C, Pimenta FC, Ito IY, Bammann LL. Antimicrobial evaluation of calcium hydroxide in infected dentinal tubules. J Endod. $1999 ; 25(6): 416-8$

10- Gomes BPFA, Ferraz CCR, Vianna MEVB, Berber FB, Teixeira FJ, Souza-Filho F. In vitro antimicrobial activity of several concentrations of sodium hypochlorite and chlorhexidine gluconate in the elimination of Enterococcus faecalis. Int Endod J. 2001;34(6):24-8.

11- Gomes BPFA, Vianna ME, Sena NT, Zaia AA, Ferraz CCR, Souza Filho FJ. In vitro evaluation of the antimicrobial activity of calcium hydroxide combined with chlorhexidine gel used as intracanal medicament. Oral Surg Oral Med Oral Pathol Oral Radiol Endod. 2006;102(4):544-50.

12- Jeansonne MJ, White RR. A comparison of 2,0\% chlorhexidine gluconate and $5.25 \%$ sodium hypochlorite as antimicrobial endodontic irrigants. J Endod. 1994;20(6):275-8.

13- Kakehashi S, Stanley HR, Fitzgerald, RJ. The effects of surgical exposure of dental pulps in germ-free and conventional laboratory rats. Oral Surg Oral Med Oral Pathol. 1965;20(3):340-9.

14- Leonardo MR, Tanomaru M Filho, Silva LA, Nelson P Filho, Bonifacio $\mathrm{KC}$, Ito IY. In vivo antimicrobial activity of $2 \%$ chlorhexidine used as a root canal irrigating solution. J Endod. 1999;25(3):167-71.

15- Love RM. Enterococcus faecalis - a mechanism for its role in endodontic failure. Int Endod J. 2001;34(5):341-5.

16- McHugh CP, Zhang P, Michalek S, Eleazer PD. pH required to kill Enterococcus faecalis in vitro. J Endod. 2004;30(4):218-9.

17- Menezes MM, Valera MC, Jorge AO, Koga-Ito CY, Camargo CH, Mancini MN. In vitro evaluation of the effectiveness of irrigants and intracanal medicaments on microorganisms within root canals. Int Endod J. 2004;37(5):311-9.

18- Nair PNR. Intraradicular bacteria and fungi in root-filled, asymptomatic human teeth with therapy-resistant periapical lesions: a long-term light and electron microscope follow-up study. J Endod. 1990;16(12):580-8

19- Najzar-Fleger D, Filipovic D, Prpic G, Kobler D. Candida in root canal in accordance with oral ecology [abstract]. Int Endod J.1992;25(1):40.

20- Safavi KE, Nichols FC. Effect of calcium hydroxide on bacterial lipopolysaccharide. J Endod. 1993;19(2):76-9. 
21- Sen BH, Safavi KE, Spanberg LSW. Antifungal effects of sodium hypochlorite and chlorhexidine in root canals. J Endod. 1999;25(4):2358 .

22- Shih MM, Marshall FJ, Rosen S. The bactericidal efficiency of sodium hypochlorite as an endodontic irrigant. Oral Surg Oral Med Oral Pathol. 1970;9(4):613-9.

23- Siqueira JF Jr, Rôças IN. Polymerase chain reaction-based analysis of microorganisms associated with failed endodontic treatment. Oral Surg Oral Med Oral Pathol Oral Radiol Endod. 2004;97(1):85-94.

24- Siqueira JF Jr, Rôças IN, Favieri A, Lima KC. Chemomechanical reduction of the bacterial population in the root canal after instrumentation and irrigation with $1 \%, 2,5 \%$ and 5,25\% sodium hypochlorite. J Endod. 2000;26(6):331-4

25- Siqueira JF Jr, Uzeda M. Desinfection by calcium hydroxide pastes of dentinal tubules infected with two obligate and one facultative anaerobic bacteria. J Endod. 1996;22(12):674-6.

26- Soares JA, Leonardo MR, Silva LB, Tanomaru Filho M, Ito IY. Effect of biomechanical preparation and calcium hydroxide on the antisepsis of root canal systems in dogs. J Appl Oral Sci. 2005;13(1):93-100.

27- Soares JA, Leonardo MR, Silva LAB, Tanomaru Filho M, Ito IY. Histomicrobiologic aspects of root canal system and periapical lesions in dog's teeth after rotatory instrumentation and intracanal dressing with calcium hydroxide pastes. J Appl Oral Sci. 2006;14(5):355-64.

28- Souza FJ Filho, Soares AJ, Vianna ME, Zaia AA, Ferraz CC, Gomes BP. Antimicrobial effect and $\mathrm{pH}$ of chlorhexidine gel and calcium hydroxide alone and associated with other materials. Braz Dent J. 2008;19(1):29-33.

29- Sundqvist G, Figdor D, Persson S, Sjögren U. Microbiologic analysis of teeth failed endodontic treatment and the outcome of conservative retreatment. Oral Surg Oral Med Oral Pathol Oral Radiol Endod. 1998;85(1):86-93.

30- Waltimo TM, Kuusinem M, Järvensivu A, Nyberg P, Väänänen A, Richardson M, et al. Examination on Candida spp. in refractory periapical granulomas. Int Endod J. 2003;36(9):643-7.

31- Waltimo TM, Sen BH, Meurman JH, Orstavik D, Haapasalo MP. Yeasts in apical periodontitis. Crit Rev Oral Biol Med. 2003;14(2):128-37.

32- Vahdaty A, Pitt Foro R, Wilson RF. Efficacy of chlorhexidine in disinfecting dentinal tubules in vitro. Endod Dent Traumatol. 1993;9(6):243-7.

33- Valera MC, Rego JM, Jorge AOC. Effect of sodium hypochlorite and five intracanal medications on Candida albicans in root canals. J Endod. 2001;27(6):401-8.

34- Vianna ME, Horz HP, Conrads G, Feres M, Gomes BP. Comparative analysis of endodontic pathogens using checkerboard hybridization in relation to culture. Oral Microbiol Immunol. 2008;23(4):282-90. 